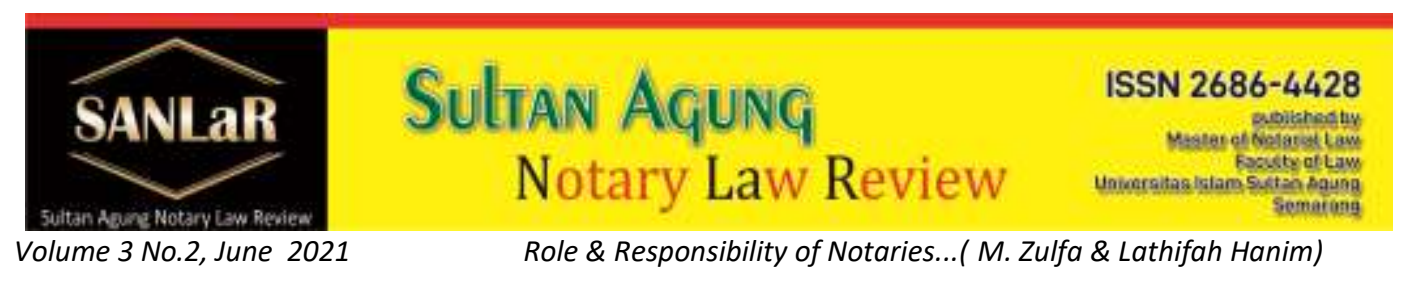

\title{
Role \& Responsibility of Notaries as General Officers in Cooperative Registration through Online System
}

\author{
Muhammad Zulfa*) and Lathifah Hanim**) \\ $\left.{ }^{*}\right)$ Faculty of Law, Universitas Islam Sultan Agung (UNISSULA) Semarang, E-mail: \\ zulfagawik66@gmail.com \\ $\left.{ }^{*}\right)$ Faculty of Law, Universitas Islam Sultan Agung (UNISSULA) Semarang, E-mail: \\ lathifah@unissula.ac.id
}

\begin{abstract}
The position of a Notary as a General Officer has the authority to make an Authentic Deed. Cooperative is a business entity which is a people's economic movement and is based on the principle of kinship. Since the promulgation of PP No. 24 of 2018, the management of business licensing in Indonesia will be carried out electronically, so it must have a Cooperative Establishment Deed which is made online by a Cooperative Deed Maker Notary, who must then obtain ratification of the Cooperative Establishment Deed. The objectives in this research include To find out and analyze the Cooperative Legal Entity Registration Procedure through the online system in Kudus Regency, To find out and analyze the role and responsibilities of a Notary in registering a Cooperative Legal Entity through the online system in Kudus Regency in case of data entry errors. To find out and analyze the legal consequences of the roles and responsibilities of a Notary in the event of an error in data entry. Based on the research concluded the role and responsibility of a Notary related to the establishment of a Cooperative is to assist in providing related counseling and draw up the Deed of Establishment of the Cooperative. After the deed of establishment, the Notary will register the ratification of the Deed of Establishment of the Cooperative through AHU Online, because without such ratification, business actors, in this case the Cooperative, cannot access OSS to administer business licenses.
\end{abstract}

Keywords: Role of Notary; Cooperative; Legal Entity.

\section{Introduction}

A notary is a public official who has the authority to make deeds related to actions, agreements and decisions which are required by general legislation or 
the parties concerned to be stated in an authentic letter, determine the date, save the deed and provide a grosse (a valid copy). The copies and quotations thereof, and all of them during the making of the Deeds are not also obligated to officials or specifically become their obligations. ${ }^{1}$

In the provisions of the Notary Position Regulations and the Notary Position Act (UUJN) it essentially states that the main task of a Notary is to make Authentic Deeds. In Article 1870 of the Civil Code it is stated that the Authentic Deed gives an absolute agreement to the parties who make it. Thus, the importance of the position of a notary is in the authority of a notary given by law to make absolute evidence or tools and therefore the authentic deed is essentially correct. So it is very important, especially for those who need it in personal or business matters.

Of the many needs for an Authentic Deed in the business sector, one of which is a Cooperative Deed. Lately, Cooperatives are the most popular form of business and are most favored by people who are involved in the business or business world because of their limited liability. Based on Act No. 25 of 1992 concerning cooperatives, article 1 explains that cooperatives are business entities consisting of individuals or cooperative legal entities based on their activities based on cooperative principles, as well as a people's economic movement on the principle of kinship.

The use of Authentic Deeds in the field of cooperatives in districts, including in Kudus Regency, is a new thing for both the community and the Notary himself. Establishment of a Notary as a Cooperative Deed Maker, Notaries are required to be able to carry out their roles professionally so that they can provide good service to people who come before a Notary to make a Cooperative Deed.

The change from manual system to electronic or online system is expected so that the registration or ratification can run more efficiently and more effectively. Not different from the previous provisions, in this new provision in its implementation still requires the role of a Notary. In the implementation of online $\mathrm{SABH}$, it is possible that there will be a problem that can become an obstacle, especially related to the role of a notary.

1 Erina Permatasari. (2017). "Peran dan tanggung jawab Notaris Terhadap Pelaksanaan Pendaftaran Badan Hukum Perseroan Terbatas Melalui Sistem Online". Dalam Jurnal Akta, $\begin{array}{lllllll}\text { Volume } & 4 & \text { No. } & 3 & \text { September } & 2017 & \text { p.401.url }\end{array}$ http://jurnal.unissula.ac.id/index.php/akta/article/view/7669 accessed on January 19, 2021 
Constraints that can occur include lack of knowledge and understanding of the Legal Entity Administration System ( $\mathrm{SABH}$ ), lack of skill in operating computers and the internet as the main means of online $\mathrm{SABH}$, and other shortcomings.

Things like this make it very possible for data entry errors or data validity to occur and even misuse of data can occur. If this happens, the consequences that arise in it are the responsibility of the Notary himself.

\section{Research Methods}

This study uses the normative juridical method to find the truth with the logic of normative legal science. In this study used descriptive analytical research specifications. This research specification aims to describe the applicable regulations comprehensively and systematically. The method of collecting legal materials is literature study supported by interviews and the analytical method used in this study uses qualitative methods.

\section{Results and Discussion}

\subsection{How to Make a Cooperative Legal Entity Deed}

Notary as a Notary for Cooperative Deed Maker, hereinafter abbreviated to (NPAK). NPAK is regulated in Article 4 of the Decree of the Minister of Cooperatives No. 98 of 2004 concerning Notaries as Cooperative Deed Making Officials, that Notaries are General Officials appointed based on the Notary Position Regulations, which are authorized by the Government to make Deeds of establishment, Deeds of amendments to the articles of association and other Deeds related to Cooperative activities.

The process of establishing a Cooperative begins with the implementation of a Cooperative Formation Meeting where for Primary Cooperatives at least 20 founding members are present, while for Secondary Cooperatives at least 3 (three) Cooperatives are present through their representatives.

The meeting for the formation of the Cooperative is attended by the Officials of the Office/Agency/Agency in charge of the local Cooperative according to the domicile of the members, where the presence of the official aims, among others, to provide direction regarding the formation of the Cooperative. The process of conducting the formation meeting as a resource person if there are questions related to cooperatives and to examine the contents of the concept of the Articles of Association made by the founders before being "deed" by the local 
Cooperative Deed Maker Notary. In addition, if possible, the establishment meeting can also be attended by a Notary Making Cooperative Deed, namely a Notary appointed through a Decree of the State Minister for Cooperatives and SMEs to assist in making/composing a Deed of Establishment, amendments to the Articles of Association and the dissolution of the Cooperative.

The establishment meeting will discuss the Articles of Association of the Cooperative which includes, among others:

a. Name and place of domicile;

b. Purpose and objectives;

c. Type of Cooperative and Field of Business;

d. Membership;

e. Meeting of members of the Supervisory and Management Board;

f. Capital;

g. Term and SHU.

h. The creation or preparation of the Deed of Establishment of the Cooperative can be made by the founders (in the event that there is no NPAK in the local area) or made by NPAK.

After the requirements from the Cooperative Service are met, namely, the Cooperative Establishment Meeting, making minutes, minutes and counseling from the Cooperative Service, the complete submission is submitted to the Notary for making the Cooperative Deed.

Then the Notary sends the documents for the establishment of a Cooperative to the District Cooperative Office using the latest system, namely Online. All files including the Deed of Establishment sheet by sheet are scanned and sent to the Cooperative Service website using a Notary account that has been registered with the Cooperative Office as a Cooperative Deed Maker Notary (NPAK). As for the process of ratifying the Cooperative with a maximum period of 6 (six) working days and a maximum of 30 (thirty) working days. In the process of ratification, the Cooperative Office checks the location where the Cooperative office will be made. 


\subsection{Cooperative Legal Entity Registration Procedure through the Online System in Kudus Regency}

In UUJN it has been regulated that the authority possessed by a Notary is to make an Authentic Deed relating to matters relating to acts, agreements and other authorities regulated by law and/or required by those who have an interest to be included in the Act. Authentic Deed, as long as the Deed to be made is not excluded, it is assigned to an official or other person who has been regulated by law. For people who need a means of proof, the Authentic Deed is very important, both in terms of business interests and in terms of personal interests.

Legal Entities are legal subjects other than humans, meaning that legal entities, like humans, have rights and obligations in the eyes of the law. According to R. Subekti, a legal entity is basically an entity or association that can have rights and act like humans, and has its own wealth, can be sued or sued before a judge. ${ }^{2}$

According to E. Utrecht Legal Entity (rechtspersoon) is a body which according to law has the power (authority) to support rights, which is not soulless, or more precisely, which is not human. A legal entity as a social phenomenon is a real phenomenon, a fact that is truly in legal relations even though it is not in the form of humans or objects made of iron, wood and so on.

According to Molengraaff, Legal Entities are essentially the rights and obligations of its members jointly, and in it are shared assets that cannot be divided. Each member does not only become the owner as an individual for each part in an indivisible unit, but also as a joint owner for the entire property, so that each individual member is also the owner of the assets organized in the Legal Entity. ${ }^{3}$

Cooperatives that already have a Deed of Establishment must apply for approval to obtain the status of a Legal Entity. Based on the provisions of the Regulation of the Minister of Law and Human Rights No. 14 of 2019 concerning the Ratification of Cooperatives (hereinafter referred to as "PERMENKUMHAM $14 / 19 ")$, the application for the approval of the Cooperative Budget is submitted by the Petitioner which in this case is carried out by a Notary as the proxy of the applicant to the Minister who carries out government affairs in the field of law through the Director General of General Legal Administration. .

\footnotetext{
${ }^{2}$ Chidir Ali, (2000) .Badan Hukum, Bandung: Alumni, p. 19

${ }^{3}$ Ali Rido, (2004)Badan Hukum Dan Kedudukan Badan Hukum Perseroan, Perkumpulan, Koperasi, Yayasan, Wakaf, Alumni : Bandung, p. 7
} 
The application is submitted in the Legal Entity Administration System (SABH), where prior to the submission of ratification, the applicant must first place an order for the name of the Cooperative. The ratification / submission of the name of the Cooperative aims to provide a specific official identity for each Cooperative that is a legal entity, and to avoid misuse of the name of the Cooperative.

PERMENKUMHAM 14/19 stipulates that the submission of the name of the Cooperative is submitted to fill out the format for submitting the name of the Cooperative to the $\mathrm{SABH}$, which at least contains the name of the Cooperative to be ordered and the type of Cooperative.

The name of the Cooperative to be ordered must consist of at least 3 (three) words after the phrase Cooperative and the type of cooperative. If the name has met the requirements and is approved, the Minister will be given electronically, in which case the approval is valid for 30 (thirty) days from the date the approval for the name of the Cooperative is given.

Application for approval of the deed of establishment of a cooperative must be submitted no later than 60 (sixty) days from the signing of the deed of establishment. The application for approval is carried out electronically by filling out the format for ratification of the Deed of Establishment and completing supporting documents in the form of a statement from the applicant regarding the completeness of the documents for the establishment of a cooperative made electronically.

The applicant who in this case is authorized to a Notary is also required to upload the Deed of establishment of the Cooperative as well as the minutes of the Cooperative in the SABH.

If the application is accepted, the Minister will issue a Ministerial Decree relating to the ratification of the Deed of Establishment of the Cooperative through electronic means, then the Notary for the Cooperative Deed Maker can print the Ministerial Decree using white F4/Folio size paper weighing 80 grams The ratification of the Cooperative will be announced in the State Gazette of the Republic of Indonesia.

The next process is to manage the Taxpayer Identification Number (NPWP) for the Cooperative. If the TIN has been issued, the founder can continue with the 
OSS (Online Single Submission) registration process to be able to obtain a Business Identification Number (NIB). ${ }^{4}$

So it can be said that the registration of cooperatives using the online system is not only practical but also faster, efficient, effective, economical, transparent and can minimize or prevent the occurrence of acts or actions that violate or conflict with the law such as committing collusion or illegal levies ${ }^{5}$.

When compared with the difference in the Online system, it lies in checking the completeness of documents which is done online, and the Notary does not need to come to the Office of the Ministry of Cooperatives to take care of the Cooperative Legal Entity. To obtain these electronic services, Notary Cooperative Deed Makers who have been registered with the Ministry of Cooperatives can access through registration with the Online system.

With this online system, it is expected to add a Cooperative Deed Maker Notary (NPAK) so that people can more easily and quickly establish a Cooperative Legal Entity.

3.3. What are the Roles and Responsibilities of a Notary in registering a Cooperative Legal Entity through the Online system in Kudus Regency in the event of a data entry error?

The role and responsibility of the Notary in the implementation of the Cooperative Deed is very necessary for those who will establish a Cooperative Business Entity, in addition to obtaining legal certainty from the Government, the position of the Cooperative is strengthened by the existence of an Authentic Deed in the form of the Deed of Establishment. The establishment of a Cooperative Deed made by a Notary as a condition to complete a legal act must be made with a Deed. The responsibilities of the Notary are related to the role of the Notary in the process of ratifying the registration of the Cooperative, the responsibilities of the Notary as a General Officer who makes the Cooperative Deed, if there is an error in the establishment of the Cooperative, it can be seen

\footnotetext{
${ }^{4}$ Widya, E., Prananingtyas, P., dan Ispriyarso, B. (2019). Pelaksanaan Penerbitan Nomor Induk Berusaha Melalui Sistem Online Submission (Studi Pendirian Perseroan Terbatas di Kota Semarang). Notarius, Jurnal Studi Kenotariatan. Semarang). Notarius, Journal of Notary Studies.

${ }^{5}$ Sukarmi \& Ong Argo Victoria. (2018). Cash Waqf in Sustaining Of Indonesian Society "In Legal \& Economic Perspective". AL-ITQAN: Journal of Islamic Sciences: IIUM Malaysia. https://journals.iium.edu.my/al-itqan/index.php/al-itqan/article/view/43
} 
in terms of errors in making the Deed of Establishment and errors in entering data.

If there is an error in data entry, the Notary is responsible for making changes to the wrong data, if the error is known at the time of the establishment preview, the data can be immediately changed within the change period for 7 days, but if the error is realized only when the SK for the establishment approval has been issued then the Notary should immediately take care of data changes by making a data change request through the SABH. ${ }^{6}$

3.4. Legal consequences on the roles and responsibilities of a Notary in the event of an error in data entry

A Notary who makes a Deed that is not in accordance with the provisions of the applicable laws and regulations can be subject to strict sanctions by the Notary Supervisory Council so that in the future it can be minimized the making of a Notary Deed that is not in accordance with the provisions of the Laws and Regulations in the field of Notary law.

Permenkumham No. 14/2019 Article 4 paragraph (1), the application for ratification of the Deed of Establishment of the Cooperative must be preceded by the submission of the name of the Cooperative. The application for the name of the Cooperative is as follows:

a. The application for ratification of the Deed of Establishment of Cooperatives is submitted by the applicant to the Minister through the Director General;

b. The applicant consists of the founders, proxies of the founders, who give power to the Notary; and

c. Applications are submitted through the Legal Entity Administration System.

According to the results of an interview with Notary Khoirul Alfian, the legal consequence of an error in data entry that applies to the roles and responsibilities of a Notary is that the Deed remains valid, but is accompanied by a Deed of changes made by the Notary accompanied by new data which is sent back to the KEMENKUMHAM with an online system., which will be followed by the issuance of a new decree.

${ }^{6}$ Notary Khoirul Alfian interview, on April 072021 
Legal Consequences on the Roles and Responsibilities of a Notary in the event of a data entry error, is not related to the ITE Law because there is no article that explicitly or implicitly states that a Notary may be subject to sanctions if he/she makes a data entry error in the registration of a Cooperative Legal Entity with the Online system. However, it is related to Article 1365 of the Notary Civil Code where the error in data entry can harm other parties so that they must compensate by correcting the data and making a Deed of amendment at a cost charged to the Notary who made the mistake.

Notaries in carrying out their duties and positions are very important to carry out the principle of prudence, especially in the process of establishing a cooperative. Notaries as humans also do not escape from mistakes, both personal and related to their position. However, notaries are required to uphold the ethics of the position that has been formulated in the code of ethics for the position of a notary.

In fact, it is possible for a Notary to make a mistake in carrying out a job, so that the error has legal consequences that harm the parties facing it.

According to Syarifin, legal consequences are all consequences that occur from all legal actions carried out by legal subjects against legal objects or other consequences caused by certain events by the law concerned have been determined or considered as legal consequences. Based on this description, to find out whether or not a legal consequence has arisen, the following things need to be considered: ${ }^{7}$

a. The existence of an act committed by a Legal Subject against a legal object or there are certain consequences of an act, the consequences of which have been regulated by law; and

b. The existence of actions that are immediately carried out intersect with the implementation of rights and obligations that have been regulated in law (law).

The process of ratifying the Cooperative through the General Legal Administration System (AHU) Online is not always problematic in the system. Problems can also occur on the Notary and on the client side as the founder of the Cooperative between the three are closely related, if there is a problem on

\footnotetext{
7Pipin Syarifin, Pengantar IImu Hukum, CV. Pustaka Setia, Bandung, 2009, p. 71.
} 
one side it will have an impact ${ }^{8}$ on the process of ratifying the Cooperative through the AHU Online System as a whole. Therefore, the notary must ensure that the deed made is in accordance with the legal rules that have been determined, so that the interests concerned are protected by the deed.

\section{Closing}

During the process of establishing a Cooperative, a Notary who in this case is a Cooperative Deed Maker Notary has a role to provide counseling to the founders. Then on the basis of the power of attorney of the founder, submit an application for approval of the name of the Cooperative. After obtaining approval, the founders make a Cooperative Establishment Deed before the Notary for the Cooperative Deed Maker. After the Deed of Establishment of the Cooperative is completed, then in less than 60 (sixty) days, the Notary, who in this case is the proxy of the founders, will submit the ratification of the Deed of establishment to the Ministry of Law and Human Rights through AHU Online. Without the completion of the ratification process by a Notary through AHU Online, business actors cannot access OSS and take care of business permits. Registration of Cooperatives using the Online system is not only practical but also faster, efficient, effective, economical, transparent and can minimize or avoid the occurrence of acts or actions that violate or conflict with the law such as committing collusion or illegal levies. When compared with the difference in the Online system, it lies in checking the completeness of documents which is done online, and the Notarydoes not need to come to the Office of the Ministry of Cooperatives to take care of the Cooperative Legal Entity. To obtain these electronic services, the Notary for the Cooperative Deed Maker who has been registered using PP No. 24 of 2018 concerning OSS through registration with the Online system. The role of the Notary is not only related to the making of the Deed of Establishment of the Cooperative, but also in other Cooperative activities. Notaries are expected to help provide advice or explanations to the founders of the Cooperative for the future development of the Cooperative. Notaries can make Cooperative Deeds as a whole, so that members of the Cooperative feel directed in building the Cooperative and Legal Consequences on the Roles and Responsibilities of a Notary in the event of a data entry error, is not related to the ITE Law because there is no article that explicitly or implicitly

\footnotetext{
${ }^{8}$ Deen, Thaufiq., Ong Argo Victoria \& Sumain. (2018). Public Notary Services In Malaysia. JURNAL AKTA: Vol. 5, No. 4, 1017-1026. Retrieved from http://jurnal.unissula.ac.id/index.php/akta/article/view/4135
} 
states that a Notary may be subject to sanctions if he/she makes a data entry error in registering Cooperatives with the online system.

\section{References}

Journals:

[1] Deen, Thaufiq., Ong Argo Victoria \& Sumain. (2018). Public Notary Services In Malaysia. JURNAL AKTA: Vol. 5, No. 4, 1017-1026. Retrieved from http://jurnal.unissula.ac.id/index.php/akta/article/view/4135

[2] Erina Permatasari, "Peran Dan Tanggung Jawab Notaris Terhadap Pelaksanaan Pendaftaran Badan Hukum Perseroan Terbatas Melalui Sistem Online", dalam Jurnal Akta, Vol 4, No 3 (2017), http://jurnal.unissula.ac.id/ accessed on 06 January 2021, at 10.00 WIB

[3] I Gusti Ngurah Wira Prabawa, "Peran Notaris Dalam Pendirian Koperasi Setelah Diberlakukannya Online Single Submission", Vol 5 No 2 August 2020, https://ojs.unud.ac.id/index.php/ActaComitas, accessed on 09 November 2020, at 09.30 WIB

[4] Nawaaf Abdullah, "Kedudukan Dan Kewenangan Notaris Dalam Membuat Akta Otentik", dalam Jurnal Akta, Vol. 4 No. 4 December 2017, http://jurnal.unissula.ac.id/, accessed on 09 November 2020, at 09.00 WIB

[5] Sukarmi \& Ong Argo Victoria. (2018). Cash Waqf in Sustaining of Indonesian Society "In Legal \& Economic Perspective". AL-ITQAN: Journal of Islamic Sciences: IIUM Malaysia. https://journals.iium.edu.my/alitqan/index.php/al-itqan/article/view/43

Books:

[1] Badrulzaman , Mariam Darus, (2005), Aneka Hukum Bisnis, Bandung : Alumni

[2] Budiono, Abdul Rachmad. (2005), Pengantar Ilmu Hukum, (Malang : Bayumedia Publishing).

[3] Hadhikusuma, Sutantya Rahardo, (2000). Hukum Koperasi Indonesia, Jakarta : Raja Grafindo Persada 
[4] Hendrojogi, (2002), Koperasi - Asas-asas Teori dan Praktek, Bandung : Raja Grafindo Persada.

[5] Khisni, Akhmad. (2015). Perkembangan Pemikiran Hukum Islam. Semarang: UNISSULA Press.

[6] Ilyas, Wirawan B., \& Suhartono, Rudy. (2012). Perpajakan. Jakarta: Mitra Wacana Media. 